UDC 616.24-002:616.12-005.4]-047.76

DOI: $10.15587 / 2519-4798.2017 .116826$

\title{
THE INFLUENCE OF COMMUNITY-ACQUIRED PNEUMONIA ON THE CLINICAL COURSE OF CORONARY HEART DISEASE: THE RESULTS OF RETROSPECTIVE ANALYSIS
}

\author{
(C) N. Mykhailovska, T. Kulynych
}

\begin{abstract}
Метою роботи було дослідити вплив перенесеної негоспітальної пневмонії (НП) на клінічний перебіг ІХС за результатами ретроспективного аналізу. Встановлено, щзо основними причинами повторної госпіталізації хворих на ІХС після НП були декомпенсація сериевої недостатності, розвиток аритмічних порушень та атеротромботичних подій. Не виявлено зв'язку між традииійними факторами ризику та розвитком несприятливих кардіоваскулярних подій після НП

Ключові слова: ішемічна хвороба серия, негоспітальна пневмонія, кардіоваскулярні подї, смертність, фактори ризику
\end{abstract}

\section{Introduction}

Cardiovascular diseases are one of the leading causes of mortality among adults; they annually cause $45 \%$ of fatalities in the European population and $37 \%$ in the European Union, which makes 4 and 1.8 million cases respectively [1]. The coronary heart disease (CHD) is the most common mortality cause in the patients with the diseases of the circulatory system in the countries of the world and Europe; in the structure of total mortality its share is $12.8 \%$ [1]. As at 2015, the CHD mortality in Ukraine was 651.8 per 100,000 of population [2].

It is known that the course of CHD is largely influenced by comorbid pathology, respiratory diseases in particular, among which the leading place is occupied by community-acquired pneumonia (CAP). As at 2015, the incidence of pneumonia in the adult population of Ukraine was 461.8 per 100 thousand, mortality consists 11.6 per 100 thousand populations [3]. It is known that $50 \%$ of all deaths in patients with CAP and more than a quarter of the deaths during the 30-day period from the onset of the disease are due to concomitant pathology, in particular with decompensation or destabilization of cardiovascular diseases, associated with a $60 \%$ increase in risk of short-term mortality in a specified category of patients [4].

\section{Research substantiation}

According to world statistics, postponed CAP exerts an adverse effect on the course of CHD [4], leading to an increase in repeated hospitalizations during 3 months of observation regarding the occurrence or decompensation of pre-existing cardiac insufficiency, the development of acute coronary syndrome, and arrhythmic complications. Data on the main factors of destabilization of the coronary artery disease course after CAP varies. Such factors include: history of heart disease, diabetes mellitus and kidney disease [5]. The highest frequency of complications was observed at the beginning of the disease and was kept elevated through 30 days of observations. Adverse cardiovascular events were associated with an increase of 9-day lethality and with such risk factors as elderly age and the pre-existing cardiovascular disease presence [6]. It should be noted that complications from the cardiovascular system were also observed in patients who did not have a history of CHD [6].

At present there are no data available on the remote effects of the transferred CAP on the CHD course. Therefore, the clarification of the characteristics of the CHD course after CAP for a longer period, the definition of the development of complications main risk factors in order to improve the treatment of this category of patients remain relevant issues of modern clinical medicine.

\section{The aim of the research}

To investigate the effect of the community-acquired pneumonia on the clinical course of coronary heart disease and the frequency of major cardiovascular events incidence based on the retrospective analysis results.

\section{Materials and methods of research}

The retrospective analysis of 203 case histories of patients with CHD (male - 105 (51.72\%), female $98(48.28 \%$ ), aged from 53 to 86 years (average $71,43 \pm 0,75$ ) score on the PSI/PORT - $80(69$; 93)), hospitalized in the therapeutic department of the "Central Clinical Hospital No. 4 of the Zavodsky District" in 2010 - 2012 because of CAP was performed. All patients were examined and received coronary heart disease basic therapy in accordance to the Ministry of Health of Ukraine Order No. 436 (2006) and the therapy of CAP according to the Ministry of Health of Ukraine Order No. 128 (2007). The study of the main cardiovascular events was conducted with each patient or his relatives through telephone conversations. The data on readmission and reference of the patient to medical institutions in the consequence of arrhythmic complications, progression of heart failure, destabilization of coronary artery disease within 1 year after the transmitted pneumonia were considered. By cumulative endpoint attributed all fatal and nonfatal cardiovascular events that occurred during the year after CAP.

The statistical data processing was carried out using the "Statistica 6.0", software package (StatSoft 
Inc, No. AXXR712D833214FAN5). The normality distribution analysis was evaluated according to Shapiro-Wilk (W) criteria. Quantitative characteristics are represented as $\mathrm{M} \pm \mathrm{m}$ (arithmetic mean \pm standard error of arithmetic mean) or Me (Q25; Q75) (median, 25 and 75 percentiles) depending on the type of distribution. Under normal distribution, the validity of the differences was estimated by the Student's t-criterion. Under the distribution, different from normal one, the Mann-Whitney U-criterion was used. Intergroup differences in qualitative characteristics were evaluated using the Pearson $\chi^{2}$ criterion (within a small sample with Yates correction). In order to assess the impact of risk factors on the clinical course of CHD, were calculated the relative risk (RR) with $95 \%$ confidence interval (CI).The differences were considered to be significant at $\mathrm{p}<0.05$.

\section{The results of research}

According to the risk of death in the result of CAP on the PSI/PORT scale, patients were divided as following: II class $(61(53 ; 67)$ points $)-60(29.6 \%)$ persons, III class $(81(76 ; 85)$ points $)-87(42.9 \%)$ persons, IV class $(104(95 ; 114)$ points $)-56(27.5 \%)$ persons. Individuals of the I and V risk classes were not registered.

Clinical characteristics of individuals in respect to the risk of a lethal outcome of pneumonia are given in Table 1 .

Table 1

Clinical characteristics of groups of coronary heart disease patients, who had a CAP, corresponding to the risk of pneumonia lethal outcome according to a retrospective analysis

\begin{tabular}{|c|c|c|c|}
\hline Indicator, unit of measurement & $\begin{array}{l}\text { II class PSI/PORT } \\
\qquad(n=60)\end{array}$ & $\begin{array}{l}\text { III class PSI/PORT } \\
(\mathrm{n}=87)\end{array}$ & $\begin{array}{l}\text { IV class PSI/PORT } \\
(\mathrm{n}=56)\end{array}$ \\
\hline Age, years & $\begin{array}{c}61.5^{* \#} \\
(54.0 ; 69.0)\end{array}$ & $\begin{array}{c}75.5 \S \\
(70.3 ; 81.8)\end{array}$ & $\begin{array}{c}80.5 \\
(74.0 ; 84.0) \\
\end{array}$ \\
\hline Men (abs./\%) & $28(46.7 \%)$ & $41(47.1 \%)$ & $33(58.9 \%)$ \\
\hline Women (abs./\%) & $32(53.3 \%)$ & $46(52.9 \%)$ & $23(41.1 \%)$ \\
\hline The history of myocardial infarction (abs./\%) & $13(21.7 \%)$ & $9(10.4 \%)$ & $14(25.0 \%)$ \\
\hline Arterial hypertension (abs. / \%) & $50(83.3 \%)$ & $73(83.9 \%)$ & $43(76.8 \%)$ \\
\hline \multicolumn{4}{|l|}{ Angina pectoris (abs./\%) } \\
\hline I FC & $2(3.3 \%)$ & - & - \\
\hline II FC & $29(48.3 \%)$ & $36(41.4 \%)$ & $17(30.4 \%)$ \\
\hline III FC & $28(46.7 \%)$ & $50(57.5 \%)$ & $37(66.1 \%)$ \\
\hline IV FC & $1(1.7 \%)$ & $1(1.2 \%)$ & $2(3.6 \%)$ \\
\hline Cardiac arrhythmias (abs./\%) & $20(33.3 \%)$ & $31(35.6 \%)$ & $22(39.3 \%)$ \\
\hline \multicolumn{4}{|l|}{ Heart failure (abs./\%) } \\
\hline I st. & $27(45.0 \%)$ & $15(17.2 \%)$ & $9(16.1 \%)$ \\
\hline II-A st. & $31(51.7 \%)$ & $64(73.6 \%)$ & $31(55.4 \%)$ \\
\hline II-B st. & $2(3.3 \%)$ & $8(9.2 \%)$ & $16(26.8 \%)$ \\
\hline Diabetestype 2 (abs./\%) & $7(11.7 \%)^{* \#}$ & $22(25.3 \%)$ & $17(30.4 \%)$ \\
\hline Obesity (abs./\%) & $25(41.7 \%)$ & $28(32.2 \%)$ & $13(23.2 \%)$ \\
\hline Smoking (abs./\%) & $19(31.7 \%)$ & $21(24.1 \%)$ & $13(23.2 \%)$ \\
\hline Body mass index, $\mathrm{kg} / \mathrm{m}^{2}$ & $\begin{array}{c}30,7 \# \\
(26,1 ; 34,1) \\
\end{array}$ & $\begin{array}{c}28,6 \S \\
(24,2 ; 32,1) \\
\end{array}$ & $\begin{array}{c}27.2 \\
(23.4 ; 29.7) \\
\end{array}$ \\
\hline Oxygen saturation, \% & $96,1 \pm 0,3 * \#$ & $94,0 \pm 0,6$ & $93.1 \pm 0.9$ \\
\hline Systolic blood pressure, mm Hg. Art. & $135,5 \pm 2,4 * \#$ & $150,8 \pm 3,5 \S$ & $131.9 \pm 4.3$ \\
\hline Diastolic blood pressure, mm Hg. Art. & $83,8 \pm 1,1 * \#$ & $87,1 \pm 1,4 \S$ & $77.2 \pm 1.9$ \\
\hline Heart rate, per min & $91,3 \pm 2,2 \#$ & $95,5 \pm 2,1$ & $99.1 \pm 3.1$ \\
\hline Glomerular filter, $\mathrm{mL} / \mathrm{min} / 1,73 \mathrm{~m}^{2}$ & $\begin{array}{c}75.7 * \# \\
(62.7 ; 92,1) \\
\end{array}$ & $\begin{array}{c}52.4 \S \\
(42.6 ; 68.6) \\
\end{array}$ & $\begin{array}{c}41.0 \\
(29.2 ; 49.5) \\
\end{array}$ \\
\hline Duration of the in-patient treatment, days & $14.0(10.0 ; 20.0)$ & $13,0(11,0 ; 20.0)$ & $13,0(8,0 ; 20.0)$ \\
\hline
\end{tabular}

Note: * - the probability of difference in rates between II and III classes of the mortality risk according to the PSI / PORT scale $(p<0.05)$; \# - the probability of difference in rates between the II and IV classes of the mortality risk on the PSI/PORT scale $(p<0.05)$; $\xi$ - the probability of difference in rates between the III and the IV classes of the mortality risk according to the PSI/PORT scale ( $p<0.05)$; Data are given as Me (Q25; Q75) or $M \pm m$, depending on the nature of data distribution, or in the absolute number of cases and their specific gravity (abs. $\%$ ) 
The groups were comparable in terms of the angina pectoris functional class, arterial hypertension history, rhythm disorders, smoking and obesity. The history of myocardial infarction was less common in patients with a third mortality risk class than in other groups, but the differences did not reach the statistical probability $\left(\chi^{2}=5.919, \mathrm{df}=2, \mathrm{p}>0.05\right)$; decompensated heart failure (HF II-B after Strazhesko-Vasilenko) was more likely to

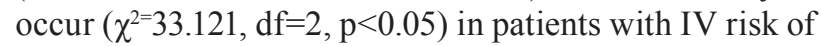
mortality class on the PSI/PORT scale; the incidence of diabetes increased with an increase in the risk of death from $11.6 \%$ (class II) to $30.4 \%$ (class IV), and was significantly higher in patients with a higher risk of death $\left(\chi^{2}=6.337, \mathrm{df}=2, \mathrm{p}<0.05\right)$. The length of the in-patient treatment was almost the same, regardless of the severity of pneumonia.

Patients with IV risk of death class had a significantly lower body mass index compared to patients with risk factors II and III (11.3 \% and $5.1 \%$, respectively, $\mathrm{p}<0.05$ ) and blood pressure values: systolic - by $2.7 \%$ lower than in patients with II- risk class, and by $12.5 \%$ lower than in patients with III risk class; diastolic - at $7.9 \%$ and $11.3 \%$ respectively ( $<<0.05$ ). With an increase in the risk of death, there was an increase in heart rate, which was significantly higher in patients with IV risk class at $8.5 \%$ compared to patients with II risk class $(p<0.05)$; the differences between the groups of patients in III and IV classes did not reach the level of statistical probability. The rate of glomerular filtration in patients with IV risk class was significantly lower in compare to patients with risk factor II $-45.4 \%$, and with patients with III risk class $-21.7 \%(\mathrm{p}<0.05)$. The indicated differences between the groups of patients were regular, since most of these factors are included in the scale of the lethal outcome risk from pneumonia PSI/PORT.

In total, in patients with CHD during 1 year after the transferred CAP 104 cardiovascular events were recorded. The most common causes of health aggravation in patients with CHD after CAP were the rhythm and conduction abnormalities, the occurrence or decompensation of pre-existing HF and deterioration of angina pectoris (Fig. 1).
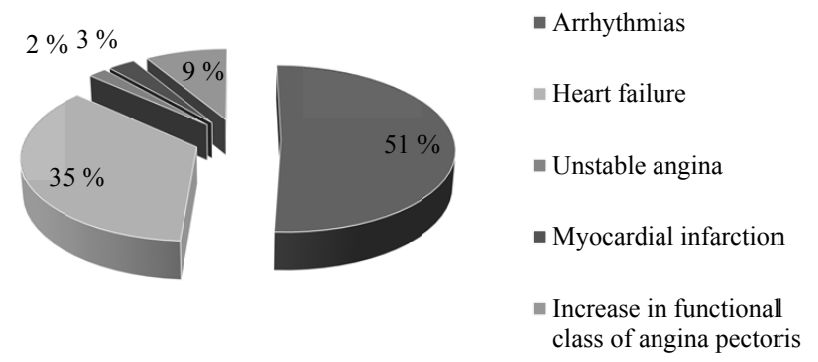

Fig. 1.The main types of cardiovascular events in patients with coronary artery disease within 1 year after $\mathrm{CAP}$ according to the data of the retrospective analysis

$37(18.2 \%)$ patients needed the re-hospitalization, of whom $2(5.4 \%)$ were hospitalized because of unstable (progressive) angina, 26 (70.3\%) - decompensation of HF, $9(24,3 \%)$ - an increase in the functional class of angina. Cardiac rhythm and conduction disturbances were the cause of hospitalization in $32(15.8 \%)$ patients: among them $15(46.9 \%)$ cases - paroxysmal atrial fibrillation, $16(50.0 \%)$ cases - of II-IV class ventricular extrasystole after B. Lown, 2 (6.3 \%) cases of AV-blockade of the I degree and 1 (3.1\%) case of the AV-blockade of the III degree. Among the hospitalized patients, $20(62.5 \%)$ had a combination of 2 or more of the complications noted. The development of acute myocardial infarction was observed in $3(1.5 \%)$ patients at 7 and 9 days from the moment of admission for hospitalization, whereas at a later date (within 1 year of observation), the noted complication was not registered.

Irregularities in rhythm and conduction, the acute myocardial infarction and decompensation of heart failure in development were observed with the same frequency in patients of all groups, regardless of the severity of pneumonia and the risk of mortality on the PSI/PORT scale (Table 2). The development of unstable angina was somewhat more common in patients with Class II risk of death as compared to patients in other groups, but the differences were not statistically significant $\left(\chi^{2}=4.800\right.$, $\mathrm{df}=2, \mathrm{p}>0.05)$.

Table 2

Peculiarities of non-fatal cardiovascular events in patients with CHD after CAP, depending on the risk class of pneumonia lethal outcome according to retrospective analysis (abs/\%)

\begin{tabular}{|c|c|c|c|}
\hline Type of event & $\begin{array}{c}\text { II class PSI/ } \\
\text { PORT } \\
(\mathrm{n}=60)\end{array}$ & $\begin{array}{c}\text { III class PSI/ } \\
\text { PORT } \\
(\mathrm{n}=87)\end{array}$ & $\begin{array}{c}\text { IV class PSI/ } \\
\text { PORT } \\
(\mathrm{n}=56)\end{array}$ \\
\hline $\begin{array}{c}\text { Violation of } \\
\text { heart rhythm } \\
\text { and conduction }\end{array}$ & $9(15.0 \%)$ & $13(14.9 \%)$ & $8(14.3 \%)$ \\
\hline $\begin{array}{c}\text { Heart failure } \\
\text { decompensation }\end{array}$ & $8(13.3 \%)$ & $15(17.2 \%)$ & $8(14.3 \%)$ \\
\hline Unstable angina & $6(10.0 \%)$ & $2(2.3 \%)$ & $2(3.6 \%)$ \\
\hline $\begin{array}{c}\text { Myocardial } \\
\text { infarction }\end{array}$ & $1(1.7 \%)$ & $1(1.2 \%)$ & $1(1.8 \%)$ \\
\hline
\end{tabular}

A fatal outcome was observed in $27(13.3 \%)$ patients, mainly up to 1 month after the onset of the development of CAP. The main causes of death were: acute myocardial infarction - 3 cases (11.1\%), pulmonary embolism - 4 cases (14.8\%), acute left ventricular failure (alveolar pulmonary edema) - 22 cases $(81.5 \%)$ (Table 3).

The fatal outcome was observed more frequently in patients with a more severe course of CAP - IV class PSI/PORT $\left(\chi^{2}=5.955, \mathrm{df}=2, \mathrm{p}<0.05\right)$. Such adverse cardiovascular events as the acute myocardial infarction development and thromboembolism of the pulmonary artery were observed with the same frequency irrespective of the severity of CAP, the incidence of acute left ventricular insufficiency increased with the severity of CAP and was the highest in patients with IV class on the PSI/PORT scale $\left(\chi^{2}=6,275, \mathrm{df}=2, \mathrm{p}<0.05\right)$. 
Table 3

Causes of death in patients with CHD after CAP, depending on the risk class of lethal outcome of pneumonia according to a retrospective analysis (abs./\%)

\begin{tabular}{|c|c|c|c|}
\hline Type of event & $\begin{array}{c}\text { II class } \\
\text { PSI/PORT } \\
(\mathrm{n}=60)\end{array}$ & $\begin{array}{c}\text { III class } \\
\text { PSI/PORT } \\
(\mathrm{n}=87)\end{array}$ & $\begin{array}{c}\text { IVclass } \\
\text { PSI/PORT } \\
(\mathrm{n}=56)\end{array}$ \\
\hline $\begin{array}{c}\text { Acute myocardial } \\
\text { infarction }\end{array}$ & $1(1.7 \%)$ & $1(1.2 \%)$ & $1(1.8 \%)$ \\
\hline $\begin{array}{c}\text { Thromboembolism } \\
\text { in the pulmonary } \\
\text { artery }\end{array}$ & $1(1.7 \%)$ & $2(2.3 \%)$ & $1(1.8 \%)$ \\
\hline $\begin{array}{c}\text { Acute left } \\
\text { ventricular } \\
\text { insufficiency, } \\
\text { amount }\end{array}$ & $4(6.7 \%)$ & $7(8.1 \%)$ & $\begin{array}{c}11(19.6 \\
\%)^{*}\end{array}$ \\
\hline $\begin{array}{c}\text { Rhythm disorders } \\
\text { Total number of } \\
\text { persons with a fatal } \\
\text { outcome }\end{array}$ & $7(11.7 \%)$ & $8(9.2 \%)$ & $\begin{array}{c}12(21.4 \\
\%)^{* \#}\end{array}$ \\
\hline
\end{tabular}

Note: *-the probability of difference between II and III classes of risk of death on the PSI/PORT scale ( $p<0.05)$; \# - the probability of the difference between the II and IV class of the risk of mortality on the PSI / PORT scale $(p<0.05)$

According to the results of the analysis (Table 4), there was not found the influence on the development of adverse cardiovascular events in patients with CHD after CAP such factors as male gender, presence of anamnesis of transmitted MI, arterial hypertension, angina pectoris III-IV FK, arrhythmic disorders, and also such traditional factors as smoking and diabetes mellitus.

Table 4

Influence of the main factors on the probable development of adverse cardiovascular events in patients with CHD after CAP

\begin{tabular}{|l|c|c|c|c|}
\hline \multirow{2}{*}{ Factor } & \multicolumn{2}{|c|}{ Cumulative endpoint } & \multicolumn{2}{c|}{ Lethal events } \\
\cline { 2 - 5 } & $\mathrm{RR}$ & $95 \% \mathrm{CI}$ & $\mathrm{RR}$ & $95 \% \mathrm{CI}$ \\
\hline Gender (male) & 1.05 & $0.72-1.53$ & 1.30 & $0.77-2.18$ \\
\hline History of MI & 0.58 & $0.31-1.11$ & 0.71 & $0.26-1.90$ \\
\hline $\begin{array}{l}\text { Cardiac } \\
\text { arrhythmias }\end{array}$ & 1.26 & $0.86-1.83$ & 0.86 & $0.43-1.73$ \\
\hline HF IIBst. & $1.81^{*}$ & $1.21-2.70$ & 1.14 & $0.43-2.97$ \\
\hline Hypertension & 0.83 & $0.53-1.31$ & 0.91 & $0.46-1.82$ \\
\hline Smoking & 1.36 & $0.89-2.10$ & 1.85 & $0.90-3.80$ \\
\hline Obesity & 0.78 & $0.49-1.22$ & 0.38 & $0.14-1.04$ \\
\hline Diabetes type 2 & 1.16 & $0.76-1.77$ & 1.44 & $0.71-2.93$ \\
\hline $\begin{array}{l}\text { IV class PSI/ } \\
\text { PORT }\end{array}$ & 1.29 & $0.87-1.91$ & $2.66^{*}$ & $1.39-5.06$ \\
\hline
\end{tabular}

Note: *-the level of statistical probability $(p<0,05)$
The presence of congestive heart failure in patients with the HF II-Bst. after Strazhesko-Vasilenko increased the probability of developing adverse cardiovascular events by 1.8 times during the year, but did not affect the development of the lethal outcome. The high risk class on the PSI / PORT scale was associated with a 2.7-fold increase in the risk of death, however, no statistically significant effect on the probability of development of non-fatal cardiovascular events was detected.

\section{Discussion of the results}

Consequently, according to the study, it was found that the survived CAP exerts an adverse effect on the CHD course due to the development of arrhythmic disorders, decompensation of heart failure and atherothrombotic events. The greatest number of deaths was observed during the first month from the onset of CAP, but a significant number of cardiovascular events were observed more lately, during the year.

There was not found a probable tie between the number of points on the PSI/PORT scale and the non-fatal cardiovascular events development, although, the incidence of acute left ventricular failure leading to death and the number of cardiovascular events increased with the severity of CAP. This coincides with the findings of other investigators [7, 8], according to which the cardiovascular complications were more frequently observed in high-risk groups in correspondence to the PSI/PORT score. The correlation between the number of points on the PSI/PORT scale and the risk of myocardial infarction development in patients hospitalized with pneumonia is also observed in others studies: the most frequent incidence of cardiovascular complications was observed in patients with IV-V risk class of death $[9,10]$. Most patients in these groups suffered of more than one type of cardiovascular complications. In addition, about one sixth of new or decompensation of already existing heart failure, one third of arrhythmias and more than two thirds of cases of myocardial infarction were observed on the same day or the next day after another cardiovascular event was determined [10].

Thus, it can be noted that the current approach to stratification of the risk of adverse events in patients with CAP on the PSI/PORT scale does not allow predicting the development of nonfatal cardiovascular complications. Therefore, it is promising to find other approaches that will stratify patients into a group of the increased risk of destabilizing the CHD course and the ways of their correction.

\section{Conclusions}

1. The survived community-acquired pneumonia exerts an adverse effect on the clinical course of coronary heart disease by increasing the functional class of angina, heart failure progress and the development of arrhythmic complications that require re-hospitalization.

2. The most common cause of the lethal outcome in patients with coronary heart disease after survived community-acquired pneumonia is acute heart failure (alveolar pulmonary edema). 
3. Non-fatal cardiovascular events were observed with the same frequency in patients with different classes on the PSI/PORT scale, regardless of severity of pneumonia. The PSI/PORT mortality risk is useful in predicting the development of fatal events, but does not provide adequate prediction of non-fatal cardiovascular events occurrence in patients with coronary heart disease who survived CAP.

4. It is prospective to search for other prognostic criteria for the coronary heart disease course after the survived CAP.

\section{References}

1. Townsend, N. Cardiovascular disease in Europe: epidemiological update 2016 [Text] / N. Townsend, L. Wilson, P. Bhatnagar, K. Wickramasinghe, M. Rayner, M. Nichols // European Heart Journal. - 2016. - Vol. 37, Issue 42. - P. 3232-3245. doi: 10.1093/ eurheartj/ehw334

2. Kovalenko, V. Problemy zdorov'ia i medychnoi dopomogy ta model pokrashchennia v suchasnykh umovakh [The problems of health and health care and it's improuvment model in modern conditions] [Text]: manual / V. Kovalenko, V. Kornatskiy. - Kyiv, 2016. $-260 \mathrm{p}$.

3. Lynnyck, M. Porivnialni dani pro rozpovsiudgenist khvorob organiv dykhannia i medychnu dopomogu khvorym na khvoroby pulmonologichnogo ta alergologichnogo profiliu v Ukraini za 2009-2015 rr. [Comparative data on the prevalence of respiratory diseases and medical care for patients with pulmonary and allergy profile diseases in Ukraine for 2009-2015 years] [Text] / M. Lynnyck, O. Nedospasova, O. Tarasenko, I. Bushura, L. Nikiforova. - Kyiv: Lira-K, 2016. - 48 p.

4. Corrales-Medina, V. F. Cardiac Complications in Patients With Community-Acquired Pneumonia: Incidence, Timing, Risk Factors, and Association With Short-Term Mortality [Text] / V. F. Corrales-Medina, D. M. Musher, G. A. Wells, J. A. Chirinos, L. Chen, M. J. Fine // Circulation. - 2012. - Vol. 125, Issue 6. - P. 773-781. doi: 10.1161/circulationaha.111.040766

5. Perry, T. W. Incidence of Cardiovascular Events After Hospital Admission for Pneumonia [Text] / T. W. Perry, M. J. V. Pugh, G. W. Waterer, B. Nakashima, C. J. Orihuela, L. A. Copeland et. al. // The American Journal of Medicine. - 2011. - Vol. 124, Issue 3. - P. 244-251. doi: 10.1016/j.amjmed.2010.11.014

6. Mandal, P. Vascular complications are associated with poor outcome in community-acquired pneumonia [Text] / P. Mandal, J. D. Chalmers, G. Choudhury, A. R. Akram, A. T. Hill // QJM. - 2011. - Vol. 104, Issue 6. - P. 489-495. doi: 10.1093/qjmed/hcq247

7. Musher, D. M. The Association between Pneumococcal Pneumonia and Acute Cardiac Events [Text] / D. M. Musher, A. M. Rueda, A. S. Kaka, S. M. Mapara // Clinical Infectious Diseases. - 2007. - Vol. 45, Issue 2. - P. 158-165. doi: 10.1086/518849

8. Viasus, D. Risk stratification and prognosis of acute cardiac events in hospitalized adults with community-acquired pneumonia [Text] / D. Viasus, C. Garcia-Vidal, F. Manresa, J. Dorca, F. Gudiol, J. Carratalà // Journal of Infection. - 2013. - Vol. 66, Issue 1. - P. 27-33. doi: 10.1016/j.jinf.2012.09.003

9. Griffin, A. T. Risk factors for cardiovascular events in hospitalized patients with community-acquired pneumonia [Text] / A. T. Griffin, T. L. Wiemken, F. W. Arnold // International Journal of Infectious Diseases. - 2013. - Vol. 17, Issue 12. - P. e1125-e1129. doi: 10.1016/j.ijid.2013.07.005

10. Ramirez, J. Acute Myocardial Infarction in Hospitalized Patients with Community-Acquired Pneumonia [Text] / J. Ramirez, S. Aliberti, M. Mirsaeidi, P. Peyrani, G. Filardo, A. Amir et. al. // Clinical Infectious Diseases. - 2008. - Vol. 47, Issue 2. - P. $182-187$. doi: $10.1086 / 589246$

Дата надходження рукопису 25.09.2017

Mykhailovska Natalia, MD, Professor, Head of Department, Department of General Practice - Family Medicine, Zaporizhzhia State Medical University, Mayakovskiy ave., 26, Zaporizhzhia, Ukraine, 69035 E-mail: natalizgmu@gmail.com

Kulynych Tamila, Assistant, Department of General Practice - Family Medicine, Zaporizhzhia State Medical University, Mayakovskiy ave., 26, Zaporizhzhia, Ukraine, 69035

E-mail: akul8@ukr.net 